Brit. J. industr. Med., 1949, 6, 65.

\title{
VESICAL TUMOURS INDUCED BY CHEMICAL COMPOUNDS
}

\author{
BY \\ M. W. GOLDBLATT \\ London
}

(RECEIVED FOR PUBLICATION, AUGUST 27, 1948)

The accumulated records of cases of vesical tumours occurring among workers in that part of the chemical industry which deals with organic intermediates, especially aromatic amines, would seem to be sufficient to justify the conclusion that there is such a thing as aromatic amine cancer. The impressive figures of Gehrmann (1936) in the United States, Müller (1933) in Switzerland and di Maio (1937) in Italy, apart from the German data, amply confirm the statement of di Maio " che i tumori e le lesioni precancerose della vescica negli operai delle fabbriche di nitro derivati sono frequentissimi," although one would wish to substitute amines for nitro derivatives. di Maio's figures are especially striking : he found between 1931 and 1937, among eighty-six workers in two factories engaged in manufacture of aromatic amines and nitro compounds, four bladder cancers, seven papillomata, and twenty-six cases of a variety of vascular lesions (simple congestions, varicosities, and telangiectasis) which he regarded as precancerous. di Maio's figures were collected by the only method which at any given time can give a true incidence of the disease in any group, viz., by cystoscopic examination of the whole group.

J. C. Bridge, who was, to the end of his life, most active in his attempts to eradicate the disease from the chemical industry and to establish an equitable basis for compensation of this, in Britain, nonscheduled industrial disease, published some striking figures in his 1933 Report to the Chief Inspector of Factories. These figures showed that in one of the smaller manufacturing towns in England where the manufacture of organic intermediates had been going on for many years, the admission to the local Infirmary of cases of bladder tumour were as follows :

1900-1910. 12 males of whom 3 were chemical labourers 1911-1921. 15 , 1922-1932. 37 ", ", ", 26 ", ", ", ",
Between 1929 and 1932 the admissions were :

1929. 5 males of whom 4 were chemical labourers

1930. 4 , , , , 4 , , ,"

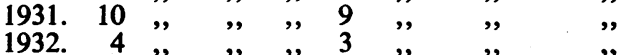

Examination of these figures shows that this Infirmary was, excluding the chemical labourers, getting an average of about one case a year and that the presence of the relatively very few chemical labourers just doubled the average for the thirty-twoyears period. In addition, it was reported that for the period 1928-32 the estimated mortality rates for this disease among chemical workers was thirtyeight times higher than for the male insured population of the town.

Having regard to the fact that in Britain, routine cystoscopy is not practised in the relevant chemical factories and that during the greater part of the period reported on by Bridge no routine urine examinations were carried out and, further, that the condition is symptomless in the early stages, and finally that there is a considerable labour turn-over in factories of this kind, we may be tolerably certain that the actual incidence of bladder tumours was at any given time higher than that recorded.

It is not our intention to review the literature on this subject but mention must be made of a recent addition to it. It has been something of a puzzle for some time that cases of vesical tumour arising in the chemical industry had not been significantly reported in France in spite of a considerable organic chemical industry. It is therefore, of interest and importance that Billiard-Duchesne should have very recently published $(1947,1948)$ an account of seventeen cases collected during recent years. The author calculated that in the factory concerned the proportion of vesical tumours among the workers was forty-three times that in the general population. In this series of cases the youngest was 39 years of age and the oldest 74 years : the mean was 53 years, 
and the author concludes that, this also being in the region of so-called spontaneous cancer, age of onset is really a "facteur second, consécutif." This is a dangerous conclusion and, without more detailed data and analysis, cannot be accepted, for the age of onset depends on the age of entry into the industry, as will be shown.

Billiard-Duchesne, like all other students of this condition, relates the disease to inhalation and absorption per cutem of the napththylamines and benzidine. Accepting five years as the minimum period of exposure necessary to induce a vesical tumour, he thinks it reasonable to recommend that no worker should be maintained in the hazardous operations for more than this period. He further considers that the French Law of Dec. 9, 1938, Art. 15, which extends to intoxications caused by aromatic amines the provision of the law of April 9, 1898 (Accidents at Work) and which would limit the period of responsibility for compensation of cases of bladder tumours to five years after leaving the injurious work, should be amended to entitle to compensation up to at least ten years after cessation of employment in the hazardous processes. Doubtless these matters will be argued in France as they have been elsewhere, and one can but hope that the well-known perspicacity of our French colleagues will succeed where as yet no finality has been reached elsewhere.

Billiard-Duchesne supports routine cystoscopy as the major method for the detection of what he rightly calls " tumeurs silencieuses" of the bladder, and states that refusal to undergo this procedure is not as frequent among workers duly informed of the , hazard of their work as it is among those who, believing themselves well, recoil from an allegedly disagreeable examination.

Another paper has been recently published in France by Désoille and others (1948). They found that, of two hundred workers in a dye factory who had worked in it for more than five years, twentyeight showed a positive qualitative test for blood in urine. Twenty-five of these agreed to be cystoscoped and twenty-three were actually cystoscoped. Of these twenty-three men, five showed bladder tumours and five showed bladder abnormalities. Four of the tumour cases had worked for many years in naphthylamines and one had worked for eighteen years in mercaptobenzthiazol (this latter, provided the worker had no other carcinogenic exposure, would be reckoned as an aniline case, since this is the only amine used in this synthesis). The five cases with bladder abnormalities showed vascular dilation, telangectases, and sub-mucous ecchymoses, changes which may be regarded as pre-neoplastic.
As a result of thus discovering 5 per cent. of the men with tumours or pre-tumour changes the investigation was " interrompue par suite du départ forcé, par la direction de l'usine, de l'un de nous," a terrible comment even in this epoch of savagery.

The attitude of workers in Britain toward cystoscopy is far from favourable. Having had an opportunity of seeing di Maio performing routine cystoscopy in an Italian factory, I can affirm that, given the right state of mind in the workers, no difficulty need be anticipated. It would appear that American and Swiss experience is similar.

There was recently an opportunity of examining the record of cases of bladder tumours in the I.G. organization in Germany; it was found that in Professor Gross's files at Elberfeld there were records of between 300 and 350 cases.

Interviews in factories of this organization elicited some interesting data.

\begin{tabular}{|c|c|c|c|c|}
\hline \multicolumn{5}{|c|}{ FACTORY LE } \\
\hline Period & $\begin{array}{l}\text { No. of } \\
\text { workers }\end{array}$ & $\begin{array}{l}\text { No. of } \\
\text { cases }\end{array}$ & $\begin{array}{c}\text { Significant } \\
\text { chemical } \\
\text { compound }\end{array}$ & $\begin{array}{l}\text { No. of } \\
\text { deaths }\end{array}$ \\
\hline $\begin{array}{c}1920- \\
1938\end{array}$ & $\begin{array}{c}500 \\
40-45 \\
?\end{array}$ & $\begin{array}{r}21 \\
20 \\
5\end{array}$ & $\begin{array}{c}\text { Aniline, Benzidine } \\
\beta \text {-naphthylamine } \\
?\end{array}$ & $\begin{array}{l}? \\
15 \\
?\end{array}$ \\
\hline
\end{tabular}

One case, specially noteworthy, was that of a worker in benzidine who developed a bladder tumour after only six months' exposure.

It was stated by medical and chemical officials that no cases had occurred among workers engaged in the manufacture and use of $\alpha$-naphthylamine (containing up to 5 per cent. $\beta$-isomer).

\section{FActory Lu}

Extract from paper by Gross (1940)

Total period since establishment of the factory .. $\quad . \quad$.. .. . Total number of bladder cancer cases $\quad \ldots 85$ $\begin{array}{lllll}\text { Aniline } & . . & . . & . . & 33\end{array}$ $\begin{array}{llll}\beta \text {-naphthylamine } & . . & . & 36\end{array}$ Aniline +

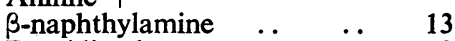
$\begin{array}{lllr}\text { Benzidine base } & . & \ldots & 13 \\ \end{array}$ Shortest period of exposure $\quad \ldots \quad$.. $\quad \ldots \quad 6$ months Latent period between cessation of exposure

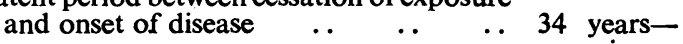
\begin{tabular}{lllll} 
Age at onset of disease &. & $\ldots$ & $\ldots$ & maximum \\
\hline
\end{tabular} Age of highest incidence $\ldots \quad \ldots \quad \ldots \quad 50-55$ years Proportion of workers in $\beta$-naphthylamine for over 5 years who developed bladder

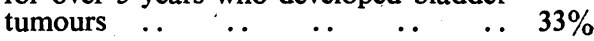

Gross stated that the age-mortality frequency curves of workers with cancer of the bladder compared with that of the general population in the neighbourhood of the works, shows that the 
shortening of life is only by a few years. It is admitted that large numbers of exposed workers could not be traced.

It will be noted that in Factory Le nearly 50 per cent. of the men in $\beta$-naphthylamine developed tumours of the bladder and something like 37 per cent. were already dead from the disease in 1938 .

Analysis of Cases of Vesical Tumours Detected in Two Factories During the Period 1934 to 1947

\section{NATURE OF THE FACTORIES}

The factories were large chemical factories engaged in the manufacture of a wide variety of organic intermediates and dyestuffs, rubber chemicals, textile finishing agents, organic primaries, and many other compounds.

The smaller of the two factories dates back to the last quarter of the nineteenth century, the larger to the twenties of the present century. Both have undergone great development both in magnitude of production and modernization of plant and process. In both, increasing awareness of the hazards has led to notable advấnces in measures designed to diminish the evolution of toxic fume and dust, to diminish skin contact with the products, and to improve the physical amenities for the workers.

Medical services have been extended and a variety of procedures introduced to determine the concentration of toxic amines in the working environment, to determine the excretion of amines by the workers, to promote diuresis in the workers, and to detect the onset at the earliest stage of exfoliation of the bladder epithelium and hæmaturia by routine microscopic examination of the urine. The effective removal of certain amines from the skin by ablution is tested by ultra-violet fluorescence, where the relevant substance gives a marked fluorescence, for example, $\beta$-naphthylamine.

Routine cystoscopy is not practised. Cystoscopy is recommended by the medical officers at such times as the condition of the urine and the history of the case appear to justify it. It is fully realized that this method of control offers no certainty that tumours will not be missed in the earliest stages. Until the attitude towards routine cystoscopy is changed and the urological technique is such as not to raise both painful memories in the experienced and anxious apprehension in the neophytes, we shall be compelled to continue the present practice, imperfect as it is.

The potential of cases built up in these factories will only be discharged in a great many years to come. The burden of study at present is to devise methods of manufacture and design of plant which will eliminate the hazard.

\section{NATURe of Processes}

The processes were a mixture of classical methods and others based on invention and experience. In the manufacture of the amines of interest in the present connexion the methods were for aniline the classical acid reduction of nitrobenzene, for $\alpha$-naphthylamine the $\mathrm{Fe}-\mathrm{HCl}$ reduction of $\alpha$-nitro-naphthylamine, for $\beta$-naphthylamine the ammonium sulphite-ammonia amidation of $\beta$-naphthol, and for benzidine the electrolytic reduction of nitrobenzene in alkaline conditions and in the presence of a suitable solvent to dissolve the hydrazo-benzene which is subsequently separated from the solvent and subjected to the usual acid treatment for conversion to benzidine hydrochloride.

The subsequent working up of these aromatic amines is so extensive and technically complex that it must suffice here to state that hundreds of different products are produced which involve greater or less processing of the amines, for example, sulphonations, nitrations, chlorinations, diazotization, alkylation, arylation, condensations with aliphatic aldehydes, hydroxylation, formation of nitroso compounds, and many others.

It is certain that, in spite of many precautions and improvements introduced in recent years, the workers do come into significant. contact with a great variety of compounds among which the supposed bladder carcinogens must be included. It would be deluding oneself to suppose that more than the first move in complete enclosure of processes has been attained. Study of plant in Germany, Switzerland, and Italy has shown that each has made some contribution to safe working principles but all have a long way still to go.

Do what we may, there are operations in this industry which inevitably expose men to dust and sometimes fumes, for example, flaking, drying, grinding, filtering. Shovelling toxic products into reaction vessels is notorious as a dust disseminator. By the expenditure of a little thought and money it is possible, for many products, to eliminate shovelling altogether by fitting a suitable adaptor to standard drums, raising the drums by suitable tackle, and tipping in the charge through the adaptor into the reactor.

With free flowing solids this can be done with ease. With a product which contains a proportion of an isomer with which a eutectic mixture easily forms, difficulties may be met with in obtaining free flow.

The German method, a good many years ago introduced into one of the factories referred to above, whereby molten $\alpha$-naphthylamine is pumped through steam-jacketed pipes to the sulphonators for production of naphthionic acid, is highly effective. 
Flaking of naphthylamines is a vastly more satisfactory procedure than solidification of condensates and subsequent breaking up and grinding. But even a good flaking machine can be a potential source of dust and fragments of amine. Whilst the chamber under the flaker in which the drums are filled through a hood can be draughted and kept very clean, the dust and débris most often seen round a well-run flaker emerges from the collecting and " doctoring" chamber.

Whatever precautions may be taken, somewhere or other a product must emerge from the plant and this point of emergence is a potent source of trouble. Ideally the toxic amine should be manufactured at a central point and distributed mechanically to peripheral plants where the subsequent stages in building up the intermediates can be carried out. In practice, this is rarely possible. Were this possible a high proportion of men would thereby be released from the need to handle, for example, $\beta$-naphthylamine. Thus, Billiard-Duchesne reports his surprise that a man working in the manufacture of $\gamma$-acid bladder tumour after twenty-three years of shovelling $\beta$-naphthylamine into the autoclave containing the sulphonating mixture. Had the amine been transferred to the autoclaves in the manner suggested above, this man might have escaped altogether.

Since nitro compounds are ubiquitous in the industry it is important to state that we have no evidence of carcinogenic properties in any of them. In a factory in which we have run control observations for many years and in which nitro-benzene is an almost universally used reaction medium and in which a great variety of aromatic nitro and amino bodies are used and made, no single case of bladder tumour has been discovered.

Similarly, we have no reason to suspect sulphonic acids.

Most observers will probably agree with these conclusions. Arising from this it may be mentioned that efforts are being made in Britain and in Switzerland and were made, we were informed, in Germany, to avoid the isolation of $\beta$-naphthylamine base by sulphonating $\beta$-naphthol to oxy-Tobias acid and subsequent amidation to Tobias acid. Higher sulphonation products from this acid can readily be prepared. Tobias acid itself is used as a first component in many azo dyes.

Some $\beta$-naphthylamine base will, however, still be required as such for certain products but the hazard will be greatly diminished if the Tobias acid synthesis is made practicable on a large scale.

Except in one concern in the U.S.A., $\alpha$-naphthy- lamine is still, as far as we know, manufactured by the classical method indicated above. If the reduction by $\mathrm{Fe}-\mathrm{HCl}$ is replaced by catalytic hydrogenation we do not remove the proportion of $\beta$-naphthylamine which is held by many investigators to be the real carcinogenic agent but we do remove the hazard of the reduction process itself. If, further, the base is distilled, transported to the point of further working up in heated tank wagons and drawn into reactors by specially adapted suction or pressure appliances with automatic devices to prevent the issue of fume, the hazard can be still more reduced.

Benzidine offers many difficult problems if any process other than the classical $\mathrm{Zn}-\mathrm{NaOH}$ reduction is used. Yet in a factory in Italy this process was operated in the most primitive conditions and we had the assurance that no bladder tumours had been discovered. The truth of this statement probably depended on the facts that (a) hydrazobenzene was not separated and (b) the conversion was carried out by direct transfer of a neutralized slurry to the conversion vat, addition of $\mathrm{HCl}$, and later precipitation of the sulphate. At no stage was it necessary for the process worker to handle hydrazobenzene or benzidine base or hydrochloride. The highly insoluble sulphate was filtered on a press and stacked in the yard.

It seems reasonable to regard benzidine sulphate as innocuous but from the industrial point of view there are objections to it. The mono- and dihydrochlorides are preferred in this country. Basification has been forbidden in the factories under my supervision for some ten years or more.

Whereas $\alpha$ - and $\beta$-naphthylamine from the nature of the flaking process inevitably emerge in a dry dusty form, benzidine hydrochloride can be maintained moist and no drying of this product has been permitted for ten years at least.

With a compound like aniline which can produce fulminating acute symptoms it is not surprising that the technique of manufacture and use should have reached higher standards of safety than in the case of the other more subtly acting toxic amines. Cyanosis due to aniline is, in a modern factory, relatively uncommon in the normal working of processes; it is common as arising from solid amines, nitro-amines, chlor-nitro-amines, and the like, which penetrate the skin and are inhaled as dust. Solids are never as impressive to a worker as toxic agents as are liquids and above all, gases.

The question of aniline as a carcinogenic agent has passed through the early phase when it was regarded as the type amino carcinogen to the present phase when it is almost entirely exonerated. It would be unwise to be over dogmatic either way. 
In the data we will present it will be at least clearr that we, in this country, must take an open view.

Certain azo compounds having been shown experimentally to be carcinogenic, it is natural to wonder whether such compounds may not be significant in our problem. It would require a rash man to answer this question with a categorical negative. Such an answer would at least be comforting to all of us having regard to the nature of some of the rsthetic shades with which we beautify our foods. The metabolism of azo

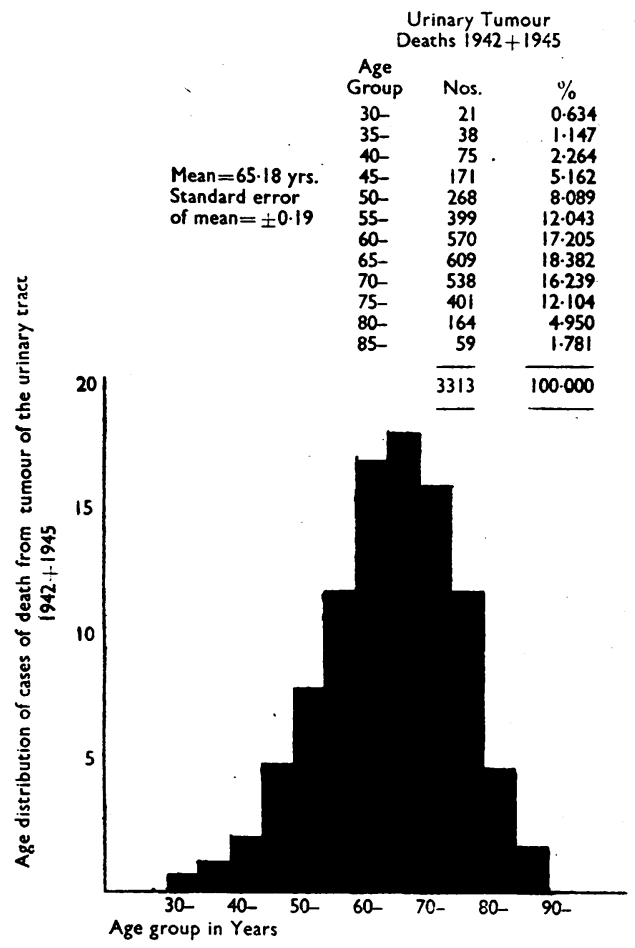

FIG. 1 o-amino azo toluene coupled with $\beta$-naphthol) provide knowledge which should lead to improved handling of such compounds, but it is not possible for us as yet to assess the weight of responsibility which compounds of this kind bear in the ætiology of bladder tumours as they occur in factories.

In condensing thus briefly some of the points in processes which appear significant in the problem of bladder tumours one cannot omit to draw attention to the manifold activities in the industry which may be called ancillary to manufacture and

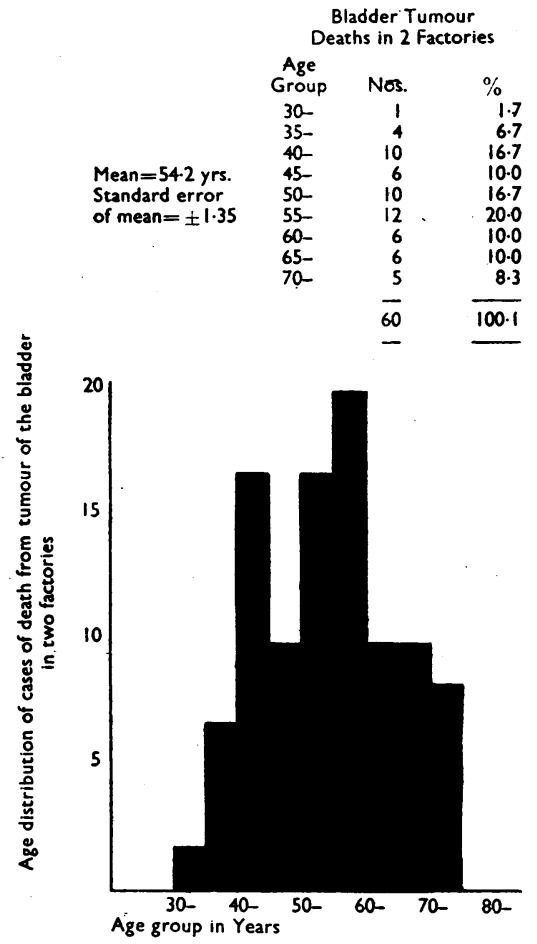

compounds in the body is still a subject requiring much more investigation. Cases of bladder tumour arising in an azo department of a chemical factory are, in general, explicable by the nature of the primary amines or diamines which are handled. Were azo compounds, as such, very significant carcinogens, we should have expected a very high incidence among workers engaged for many years in the grinding and mixing of a great variety of simple and complex azo dyes. This is not, however, the case, and hence for the time being we are not in a position to be even approximately certain about azo compounds. The experimental results obtained with, for example, o-amino azo toluene, p-dimethylamino azo benzene, and scarlet red (diazotized which lay men open to the dangers of carcinogenic agents. We will present data on workers who, whilst never employed in process work, yet developed bladder tumours. This is a matter of great moment in any attempted formulation of a scheme of legal compensation, for to restrict compensation only to men engaged on prescribed processes in a factory manufacturing organic intermediates would be highly unjust.

\section{Analysis of Cases}

In the data now to be presented the cases from the two factories referred to have been considered together. All the patients (except one) were men who belonged to the same social stratum, worked 
and lived in adjacent counties, and consumed similar diets, and they are not likely to have differed much in intellect or habit.

TABLE 1

ANNUAL INCIDENCE OF NEWLY ARISING VESICAL TUMOURS AND OF DEATHS FROM VESICAL TUMOURS IN TWO FACTORIES IN BRITAIN*

\begin{tabular}{l|c|c|c|c|c}
\hline Year & $\begin{array}{c}\text { Total No. } \\
\text { workers } \\
\text { in 2 } \\
\text { factories }\end{array}$ & $\begin{array}{c}\text { No. of } \\
\text { tumour } \\
\text { cases } \\
\text { coming } \\
\text { to light }\end{array}$ & per 106 & $\begin{array}{c}\text { Deaths } \\
\text { from } \\
\text { tumour }\end{array}$ & per 106 \\
\hline 1934 & 2,025 & 7 & 3,456 & 1 & 493 \\
1935 & 2,379 & 6 & 2,522 & 2 & 840 \\
1936 & 2,414 & 8 & 3,315 & 1 & 414 \\
1937 & 2,555 & 3 & 1,174 & 1 & 391 \\
1938 & 2,225 & 12 & 5,392 & 7 & 3,146 \\
1939 & 2,815 & 8 & 2,842 & 3 & 1,065 \\
1940 & 3,183 & 4 & 1,257 & 5 & 1,571 \\
1941 & 3,066 & 7 & 2,283 & 3 & 978 \\
1942 & 2,952 & 4 & 1,355 & 6 & 2,033 \\
1943 & 2,723 & 9 & 3,305 & 5 & 1,836 \\
1944 & 2,808 & 6 & 2,137 & 6 & 2,137 \\
1945 & 2,939 & 12 & 4,083 & 8 & 2,722 \\
1946 & 3,863 & 7 & 1,811 & 6 & 1,554 \\
1947 & 4,163 & 6 & 1,441 & 5 & 1,201 \\
\hline & & 99 & & $59 \dagger$ & \\
\hline
\end{tabular}

* The Table records cases from ages 30 - to 70 , and cases wer sometimes reported from retirement. Retired cases were reported in respect of possible ex gratia compensation. There is little doub that the total incidence is higher, since some cases are missed through the men leaving the districts and doctors not knowing about the industrial aspects of the disease.

$\dagger$ The disparity between 59 in the Table and 60 in fig. 1 is due to the absence of the necessary data other than age in one case.

Comparisons between data of this kind and national figures are subject to certain difficulties. First of all we have no published national record of morbidity: secondly, we have no published national records of death due to bladder tumours but only of deaths due to all tumours of the urinary tract : thirdly, the age distribution of a fluctuating population such as we normally find in a large factory is difficult to correct for : fourthly, the social stratum from which the workers in the two chemical factories are drawn is that with which higher incidences of neoplastic disease is associated : fifthly, we do not know the numbers of men engaged in the particular branch of the chemical industry throughout the country nor the annual incidence of bladder tumours among them. Hence, although the incidence of deaths shown in Table 1 far exceeds the incidence of deaths for all urinary tumours in the country $(1,623$ out of a male population of $16,802,000$ in 1942 and 1,758 out of a male population of $16,412,000$ in 1945) it is perhaps more reasonable to compare with a similar population drawn from the same social stratum, employed on similar work but not using or making certain compounds and subject to a labour turnover of a similar kind. Since the two factories are associated with a group of factories spread over the country and engaged in different stages of the manufacture of dyes, pigments, and paints, but not in the production of primary aromatic amines (although these were used), and since the total number of workers in the group is about equal to that of the two factories, and since, further, the reported incidence of bladder tumours in the group is quite negligible and of deaths due to bladder tumours has been zero during the last thirteen years, it seems not unreasonable to associate the disease in the two factories with the manufacture of the amines. The expected incidence of deaths due to urinary tumours as a whole in a representative sample of the male population between the ages of 20 and 65 in England and Wales is less than 1 in 10,000 , probably more nearly 1 . in 20,000 for bladder tumours, so that an average incidence of 4.2 deaths per annum for a group of 2,000 to 3,000 men requires little comment.* Perhaps even more impressive is the consistency of the incidence of both newly appearing tumours and deaths.

If now, we proceed to consider the age distribution of these deaths it becomes apparent that the disease is one attacking its victims at ages much lower than those found among the general population.

Whereas some 4 per cent. of deaths due to urinary tumours in England and Wales at ages over 30 occur at ages' less than 45 (1942 and 1945), in our industrial bladder tumour cases over 25 per cent. fall within the same age limit. This important difference is shown graphically in fig. 1, and depends upon the age at which the worker enters the industry. This is shown in fig. 2.

The implication of this is not that young men are more susceptible to the disease than are older men ; on this we have found no data and, even if we had, rigid conclusions would have been dangerous in view of the impossibility of assessing the intensity of exposure to the hazards. The implication is simply that young men if they later develop a tumour and die from it, will in a great proportion of cases, die young. The same thing can be inferred from the mean time between entry into the industry and the onset of a tumour (nineteen years with a standard error of only 0.8 ) having regard to the

\begin{tabular}{|c|c|c|c|}
\hline & Males & $\begin{array}{l}\text { Urinary tumour deaths } \\
\text { between ages } 20 \text { and } 65\end{array}$ & Deaths per $10^{4}$ \\
\hline $\begin{array}{l}1942 \\
1943\end{array}$ & $\begin{array}{l}16,802,000 \\
16,412,000\end{array}$ & $\begin{array}{l}1040 \\
1118\end{array}$ & $\begin{array}{l}0.62 \\
0.68\end{array}$ \\
\hline
\end{tabular}



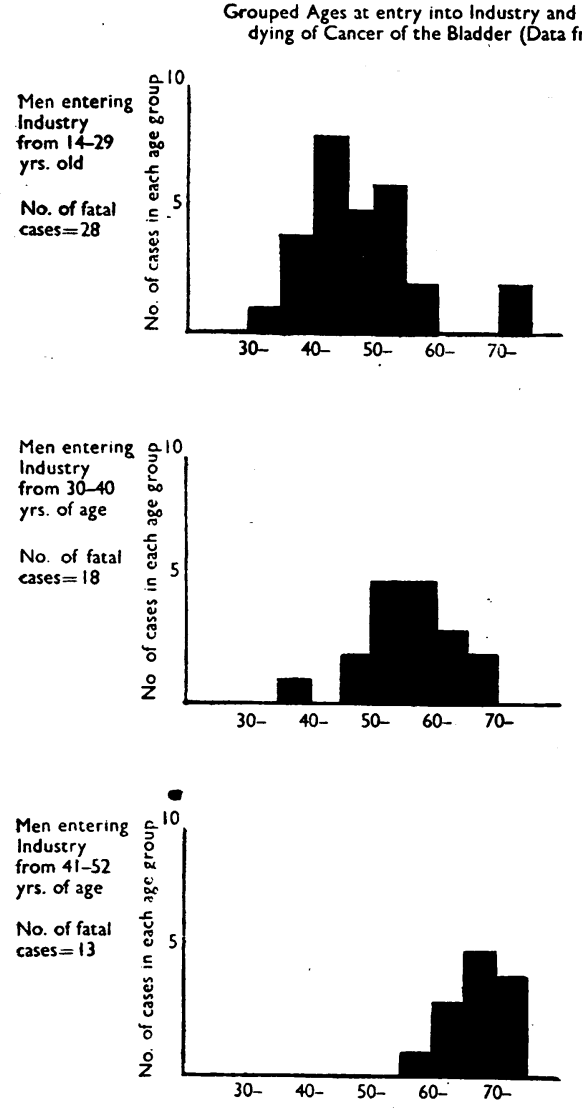

FIG. 2

high mortality (vide infra). But an implication that must be faced is that young men should not enter the industry so long as there is reason to believe the hazard of bladder tumour continues and if it is held that one of the objects of industry is, as far as possible, to assure all employees a reasonable length of working life. This course is not proposed as a substitute for making the dangerous processes safe. It is proposed because it is an extremely difficult matter to make them safe and because young inexperienced men are more likely to take risks and less likely to believe that they can sustain a serious damage from apparently innocuous substances.

This view on the employment of young men is contrary to that of well-known authorities on this problem and, until such time as the hazard is overcome, we will continue to maintain it.

In fig. 3 we present the frequency in $93^{*}$ cases of different age groups at which tumours were first recognized. It is seen that 33 per cent. of the cases

\footnotetext{
* In only 93 cases was the necessary information available.
}

were diagnosed before the age of 45 . When it is remembered that the method of detection of the onset of the growth was routine urine examination and not routine cystoscopy, it will be clear that the mean age of onset is less than the 50.55 given in the Table. As already stated above, the real determinant of the age of onset is the age at which the industry is entered. $t$ We are not in a position to assess such factors as constitutional disposition to cancer. It may. be that a family history of neoplastic disease is a significant factor. It is the fashion to prescribe that persons with a family history of neoplastic disease should not be employed in the industry. It may be that some indũstrial medical officers can elicit an informative family history from workers ; most will probably agree that this is no easy matter. It is stated that not all workers in the hazardous processes develop bladder tumours. Hueper (1946) states that from 30 per cent. to 90 per cent. of workers in these processes develop tumours. We have recorded reminiscences of works chemists who had worked in some of these processes for many years and who stated that substantially every man they had had in the plant years before had since died of cancer of the bladder. The importance of maintained exposure to the hazardous compounds is indicated by the rarity of bladder tumours among chemists who have been in charge of the processes for many years. In our series of 102 cases up to date, only one chemist appears as having developed a bladder tumour and his works history indicated a much greater contact with the compounds than is nowadays usual for chemists in manufacturing plant. He was engaged for many years in the actual manufacture of many diamines, including benzidine, in a small factory since closed down : other contacts were $\alpha$-naphthylamine and aniline.

When tabulations are made of the periods elapsing between first entry into the industry and

+ There is no constancy of the period between age of onset and There is no constancy of the period between age of onset and
age of entry, for different age groups; for example, a man entered the industry as a boy of 14 years of age and developed a tumour at 70 years of age. Clearly the determining factor (mentioned elsewhere 70 years of age. Clearly the determining factor (mentioned elsewhere
in the paper) is the degree of exposure over years, which is not in the paper) is the degree of exposure over years, which is not
measurable, and some perhaps constitutional predisposition. More research will be needed on this question. 
the first discovered signs of tumour Ages at first recognition of tumours (living and dead cases) wrere known. formation, emphasis is usually laid upon the minimum period at which a tumour may be found. In fig. 4 a distribution of periods elapsing is given for 100 cases in our series which yields a mean of some nineteen years (standard error 0.8).

These cases may, of course, have developed the tumour whilst in the industry or many years after having left it. Thus, as a typical example, we have the case of S.H.H. who worked in $\beta$-naphthylamine for three and a half years, left the industry, and died of carcinoma of the bladder twelve years later at the age of 57 years.

Another case of interest was a man who had worked in the industry for one year, and three months from the time of starting was found to have a small sessile papilloma above the left ureteric orifice. In spite of statements that six months' exposure may be sufficient to lead to tumour formation (Koelsch, 1935), this case was recorded as non-occupational. The single case in fig. 4 developing a tumour in less than six years was a

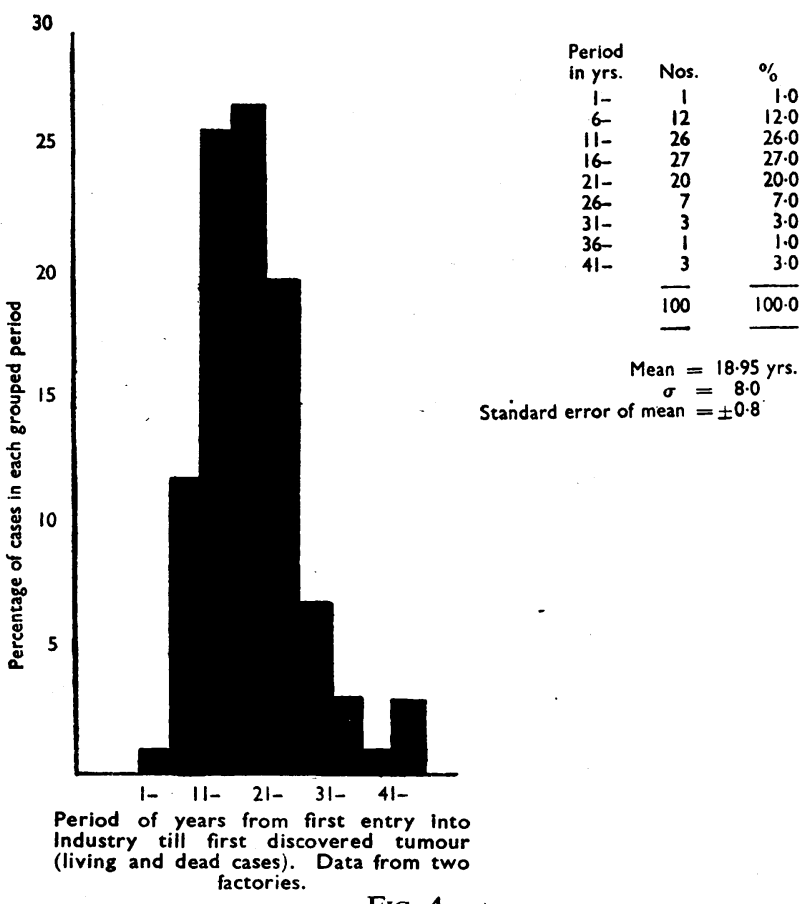

FIG. 4

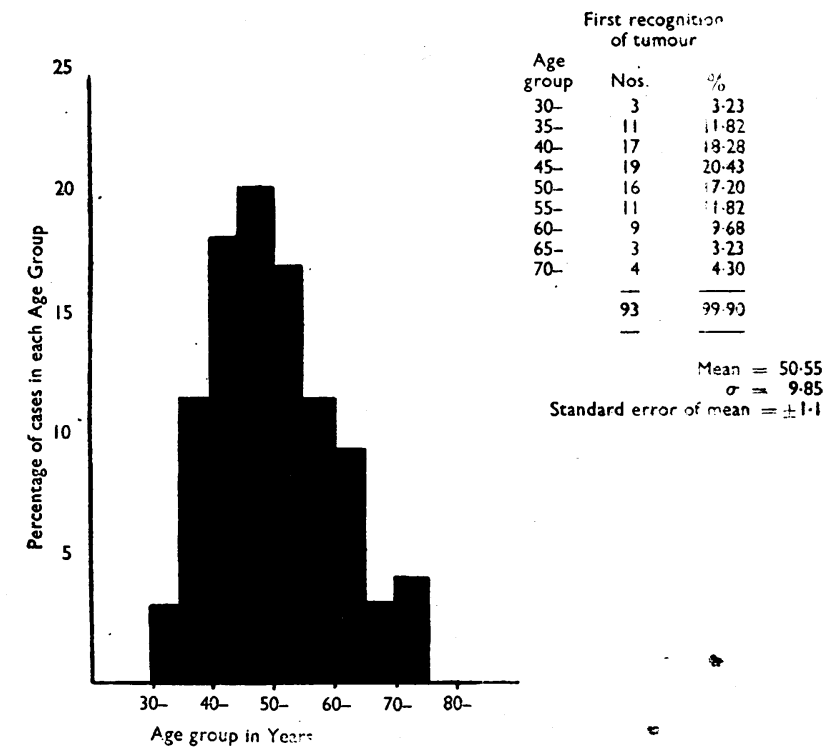

FIG. 3

fitter who for two years was engaged in the maintenance of $\beta$-naphthylamine autoclaves: he had no further contact, and two years later developed a bladder papilloma, that is, four years after entering the industry. This was the shortest period of exposure and the shortest latent period in the present series. This man had a recurrence twenty months after the first tumour was fulgurated and now, nine years afterwards, is apparently quite well.

The root problem in the pathology of the disease lies in this Table, for what must ultimately be determined is the nature of the change in the bladder (mucous membrane or connective tissue) which can manifest itself as a tumour many years after cessation of exposure.

Some experimental work in the U.S.A. (referred to privately by Dr. Gehrmann) appears to have shown that $\beta$-naphthylamine can be demonstrated in the bladder tissue of animals years after the last dose had been administered. If this were confirmed it would not remove the dilemma of imagining a carcinogen quiescently in contact with a tissue for, in some cases, forty years. Perhaps it could be more easily imagined if, as was suggested in a former paper (Goldblatt, 1947), the amine were a potentiator of the tissue which must await 
the adequate concentration of endogenous carcinogen to develop a tumour. Production of tumours in animals could, on this view, be regarded as resulting from an enormous amount of potentiator to produce the necessary and sufficient conditions for a very small available amount of carcinogen to be effective to produce a tumour.

The pre-cancerous vascular changes which are seen in the bladder might be regarded as the signs of the action of the potentiator. There is no doubt that exfoliation of bladder epithelium, intermittent microscopic hæmaturia, and leucocytes in the urine can proceed for months and even years without any overt tumour being detectable cystoscopically.

The occupational variety of bladder tumour is almost always preceded by one or other or all of these signs. It is true that a tumour may occasionally be present without hæmaturia being detectable, but more or less bladder epithelium is always to be found in the urine of these cases.

But it is not so easy to picture what is occurring when at the time of leaving the industry no signs whatever can be detected in the urine and yet a tumour develops after a few or many years without any further industrial exposure. Parallel problems are, of course, to be found in various kinds of occupational neoplastic disease.

The nature of the substance or substances which are responsible for setting in train the process of tumour development in the bladder is not yet known with certainty. Whereas $\beta$-naphthylamine has been shown experimentally to be a carcinogen in dogs, it must be allowed that the doses used to produce tumours have been enormous. In Table 2 we set out some data to give an idea of the order of excretion of aromatic amine among workers engaged in the manufacture of $\alpha$-naphthylamine in conditions at first bad and later much improved. Since the determinations were carried out on "grab" samples, an assumption had to be made of the total daily volume of urine. The volume assumed was $1,500 \mathrm{ml}$. The numbers of samples tested were 119 in 1942, 100 in 1943, and 100 in 1944.

Conditions in these plants were progressively improved with resulting great diminution in excreted amine but, even at the worst period, average excretion did not exceed 1-2 mg. per $\mathrm{kg}$. body weight per day (assuming average body weight to be about $70 \mathrm{~kg}$.) and was reached at only two spots in 1942. This is shown also in Table 3. Here we see that in 1942, 21. per cent. of the samples, in 1943 only 7 per cent., and in 1944 only 6 per cent. exceeded $61 \mathrm{mg}$.

If we take these figures as some indication of the degree of absorption of amine, it is at once seen how the dosage of dogs by, for example, Bonser (1943) exceeds the absorption found in practice. This investigator started her dogs on $150 \mathrm{mg}$. per

TABLE 2

AVERAGE DAILY EXCRETION OF AROMATIC AMINE PER WORKER PER 1,500 ML. URINE (AS MG. $\alpha$-NAPHTHYLAMINE)

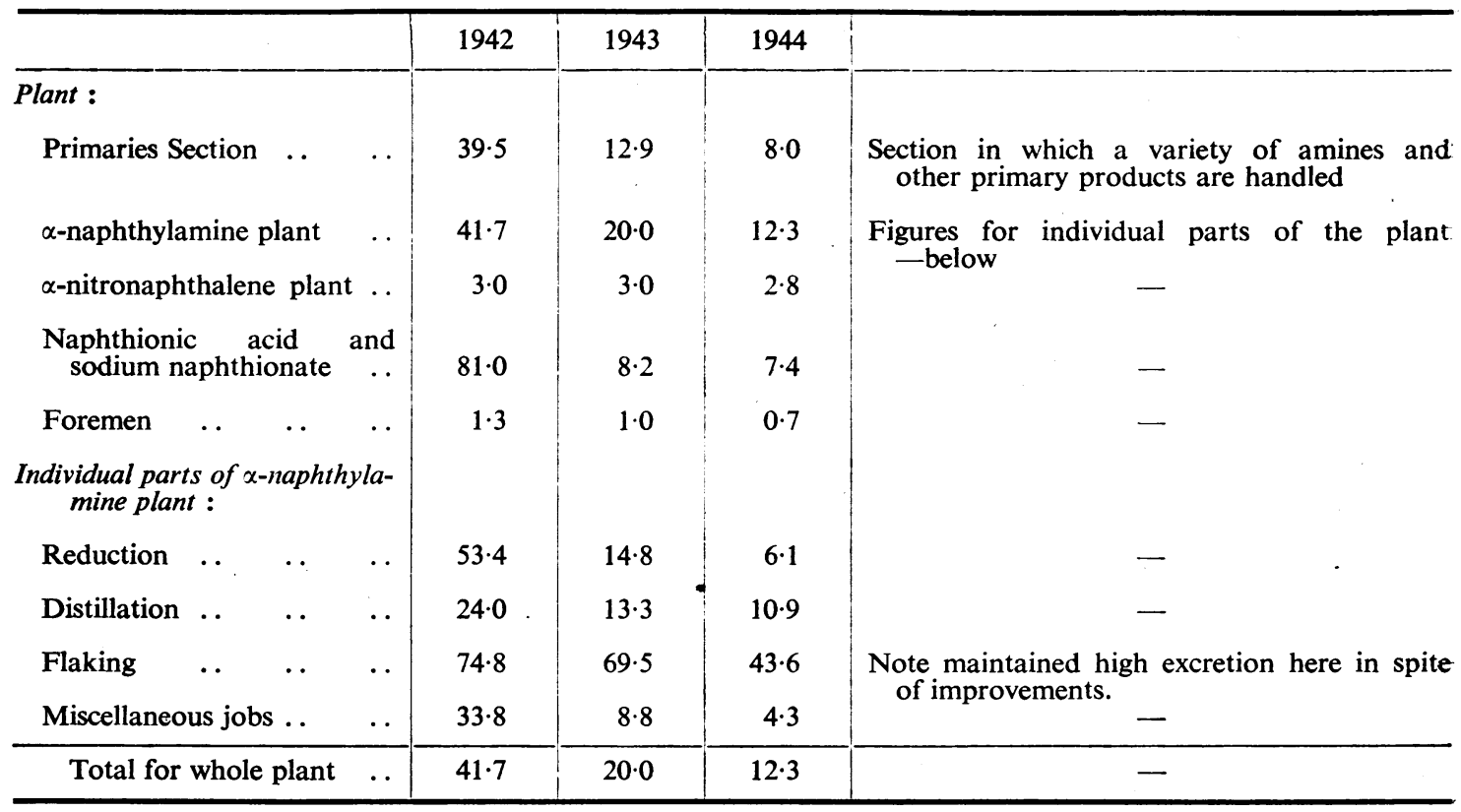


day of $\beta$-naphthylamine, and changed over to $100 \mathrm{mg}$. per day because of hæmaturia ; but after the first year of treatment the dose was gradually raised to $700 \mathrm{mg}$. per day.

TABLE 3

DISTRIBUTION OF AMINE CONTENT OF WORKERS' URINE ; PERCENTAGE OF SAMPLES ANALYSED

\begin{tabular}{|c|c|c|c|c|}
\hline Amine, mg. & & 1942 & 1943 & 1944 \\
\hline $\begin{array}{r}<2 \cdot 0 \\
2-\ldots \\
21-\ldots \\
61-\ldots \\
120-\ldots\end{array}$ & $\begin{array}{l}\cdots \\
\cdots \\
\cdots \\
\cdots\end{array}$ & $\begin{array}{r}5 \cdot 9 \\
42 \cdot 9 \\
30 \cdot 2 \\
15 \cdot 1 \\
5 \cdot 9\end{array}$ & $\begin{array}{r}35.0 \\
50.0 \\
18.0 \\
3.0 \\
4.0\end{array}$ & $\begin{array}{r}61 \cdot 0 \\
24 \cdot 0 \\
9 \cdot 0 \\
4 \cdot 0 \\
2 \cdot 0\end{array}$ \\
\hline No. of samples & $\ldots$ & 119 & 100 & 100 \\
\hline
\end{tabular}

Now when it is remembered (1) that it is in conditions such as the above that tumours develop, and (2) that the $\alpha$-naphthylamine produced in this plant contains only 3 per cent. or 5 per cent. of $\beta$-naphthylamine, then the doses given by Bonser seem fantastically large in relation to what is needed for a man (if we accept the widely held view that $\alpha$-naphthylamine as such is not tumour-producing).

Whilst Bonser's experiments leave no doubt that $\beta$-naphthylamine can lead to bladder tumours in dogs, it is desirable to simulate the human situation by giving doses which are entirely undisturbing.

Experimental evidence that primary aromatic amines other than $\beta$-naphthylamine are tumourproducing has not as yet been published, as far as we know. Evidence from the nature of the exposure of affected workers is difficult to elicit, for, from the nature of the industry, maintenance of workers on single processes is not, in general, possible. The matter is made still more difficult by bladder tumours appearing in men who were not officially attached to any of the suspected processes.
In our series of cases it has been possible to pick out men who were, owing to special circumstances, attached exclusively to one process. Thus, the $\alpha$-naphthylamine process was carried out in an old plant which had been modernized in many important respects (although still unsatisfactory), and there were men who had been associated with it exclusively for many years. In the case of $\beta$-naphthylamine the process had gone through some vicissitudes since up to some ten years ago it had been one of several processes which stood in a single large shed (and had affected a number of men who officially had nothing to do with the process itself) and since that time has stood on a separate site and has become more or less an open-air process. This process and those for aniline and benzidine are located in another town some thirty miles away from that for $\alpha$-naphthylamine.

Men who had been associated only with the manufacture of aniline, benzidine, or $\beta$-naphthylamine were picked out. Such men are by no means the only ones to have been in contact with these products.

It has thus been possible to construct tables of fifty-eight cases of bladder tumours among men with different known times and nature of exposures and of eighteen cases among men the nature of whose exposures were known but the times unknown (Tables 4 and 5). Of these fifty-eight cases, 26 were of papillomata at the start and thirty-two were of carcinomata at the start.

It will be observed that the proportion of cases in Table 4 starting as carcinoma is greatest where $\beta$-naphthylamine has been the only chemical suspect or one of the chemical suspects. In only one of these cases was a papilloma diagnosed : in one diagnosis was doubtful (Table 5).

It will be noticed also that in all but two cases of these groups of cases $\beta$-naphthylamine was manufactured or handled.

TABLE 4

NATURE OF FIRST TUMOURS: PERIOD AND NATURE OF CHEMICAL EXPOSURE

(Only those cases are included in which periods in specific substances are known with some accuracy)

\begin{tabular}{|c|c|c|c|c|c|c|c|c|c|c|}
\hline $\begin{array}{l}\text { Period in } \\
\text { various } \\
\text { substances } \\
\text { (yrs.) }\end{array}$ & $\mathrm{Ar}$ & nly & $\alpha$-nar & mine & $\beta$-nap & mine & Ben & only & $\begin{array}{l}\text { Mixe } \\
\text { incly }\end{array}$ & $\begin{array}{l}\text { osure } \\
\text { ll the } \\
\text { ig }\end{array}$ \\
\hline & $\mathbf{P}$ & C & $\mathbf{P}$ & C & $\mathbf{P}$ & C & $\mathbf{P}$ & C & $\mathbf{P}$ & C \\
\hline $\begin{array}{l}1- \\
6-\end{array}$ & - & - & 1 & - & 3 & $\begin{array}{l}2 \\
8\end{array}$ & - & I & $\overline{1}$ & $\begin{array}{l}3 \\
4\end{array}$ \\
\hline $11-$ & 1 & - & 3 & 1 & 1 & 2 & 1 & 1 & 2 & 2 \\
\hline $16-$ & - & - & 1 & - & 2 & 1 & 2 & 1 & - & 2 \\
\hline $21-$ & 1 & - & 3 & 1 & - & - & - & - & - & 2 \\
\hline $20-$ & 1 & - & - & 1 & - & - & & - & - & 一 \\
\hline & 3 & 0 & 8 & 3 & 9 & 13 & 3 & 3 & 3 & 13 \\
\hline
\end{tabular}


TABLE 5

NATURE OF FIRST TUMOUR OR TUMOURS IN MEN WHOSE PERIODS OF WORK IN VARIOUS PROCESSES ARE NOT KNOWN

\begin{tabular}{|c|c|c|c|c|c|}
\hline $\begin{array}{l}\text { No. of } \\
\text { cases } \\
\text { (18) }\end{array}$ & $\begin{array}{l}\text { Nature of } \\
\text { tumours }\end{array}$ & Aniline & $\begin{array}{c}\alpha- \\
\text { naphth. }\end{array}$ & $\begin{array}{c}\beta- \\
\text { naphth. }\end{array}$ & $\begin{array}{l}\text { Benzi- } \\
\text { dine }\end{array}$ \\
\hline $\begin{array}{l}2 \\
2 \\
4 \\
3 \\
4 \\
1 \\
1 \\
1\end{array}$ & $\begin{array}{c}\stackrel{C}{C} \\
3 \mathrm{C} ; 1 ? \\
3 \mathrm{C}, 1 \mathrm{P} \\
\stackrel{C}{\mathrm{C}} \\
\mathrm{C}\end{array}$ & $\begin{array}{l}+ \\
+ \\
+ \\
+ \\
+ \\
+ \\
+\end{array}$ & $\begin{array}{l}+ \\
- \\
- \\
+ \\
+ \\
+ \\
+\end{array}$ & $\begin{array}{l}+ \\
+ \\
+ \\
+ \\
+ \\
+ \\
+\end{array}$ & $\begin{array}{l}+ \\
+ \\
+ \\
+ \\
- \\
+\end{array}$ \\
\hline
\end{tabular}

If aniline and $\alpha$-naphthylamine, benzidine and $\beta$-naphthylamine, and mixed exposures are regarded as three groups giving increasing proportions of carcinoma (Table 4), it is perhaps just permissible to calculate $\chi^{2}$ for a grouping of this kind and size ; $\chi^{2}=10.87, P<0.01$. The reasonable nature of the conclusion expressed as $\mathbf{P}<0.01$ is shown in Table 5, where of eighteen cases of the mixed-exposure kind but with unknown lengths of exposure to each hazard, only one case was diagnosed as papilloma, all the rest being malignant from the start (one not diagnosed at the start).

The implication from our records is that tumours of the bladder developed by men exposed to mixed amines each suspected of carcinogenic effects are very likely to be malignant at the start.

It may be recalled that Engel (1937) considered that the compounds to which workers were exposed had a certain influence on the type of tumour later developed. For instance, he thought $\beta$-naphthylamine more likely to give rise to papillomata and aniline and benzidine more likely to give rise to malignant tumours. It is difficult to conclude on this matter and we are loath to go further than the above statement in relation to mixed exposure which seems very strongly supported by our data.

With regard to the basic problem of whether the four amines are all tumour-forming, our data leave no doubt that men engaged on each of the processes do develop tumours. Whether the effects of $\alpha$-naphthylamine are due to its undoubted content of the $\beta$-isomer, can finally only be settled by experiment and by manufacturing pure $\alpha$-naphthylamine for a sufficiently long time. Experiment has hitherto been negative.

The question of aniline carcinogenicity has, as stated above, gone through various stages until now there is some doubt as to its possessing such a property. Experimentally, results have been variable, some workers having reported tumours of the bladder but the more sceptical have reported consistent failure. Cases reasonably attributable to aniline only are uncommon in our experience but it must be remembered that effective precautions can be and most often are taken in the manufacture and handling of aniline and its near homologues, as is shown by the relatively infrequent occurrence of cyanosis among the workers in them. Hardly a writer on this subject fails to present cases which must be attributed to aniline. The recent report of Billiard-Duchesne of a man who had worked on making mercaptobenzthiazole (vide supra) is of interest to us because quite recently we have noted a good deal of maintained microscopic hæmaturia among workers manufacturing rubber chemicals including mercaptobenzthiazole. This compound and others (for example, diphenylguanidine and diphenylurea) involves the exposure of men in greater or lesser measure to aniline. Provided other exposures can be held to be innocuous, cases arising among these men must be attributed to aniline.

Bladder tumour cases attributed to the benzidine process only are also relatively uncommon in our experience but of their reality there seems little doubt. By whatever process benzidine is made ( $\mathrm{Zn}-\mathrm{NaOH}$ reduction, electrolytic, $\mathrm{Na}-\mathrm{Hg}$ method) cases have been described as occurring in it. Except nitrobenzene the only aromatic compounds arising in the process are hydrazobenzene, benzidine, small amounts of azo-benzene, azoxy-benzene, and diphenylene. Experimentally benzidine has so far failed to give evidence of carcinogenic action whether administered intraperitoneally, by mouth, as vapour, or by skin painting. Azo-benzene and azoxybenzene have not, as far as we know, ever been shown to be tumour forming: hydrazobenzene and diphenylene $\left(2: 4^{\prime}\right.$ isomer of benzidine) do not appear to have been tested.

In the experiments with benzidine and aniline dogs do not appear to have been used. Since the most striking results on bladder carcinogens have been obtained with dogs, it seems desirable to use this species. for testing other suspected bladder carcinogens in spite of the tedious and trying nature of such experiments. Benzidine is a much more acutely toxic compound than the naphthylamines so that dosage will probably present some problems.

Tumours Developed in Workers other than Process Workers : All Mixed Exposures.-In Table 6 we record briefly the cases of tumours detected in the two factories in the course of the last twelve years among workers who, whilst not engaged on process work in the usually accepted sense, were undoubtedly exposed to the suspected compounds. The 
exposure of a fitter in a hazardous plant is obvious : a cooper might have to enter the plant to examine and remove faulty containers for repair and would, unless the containers were rigorously cleansed, come into close contact with a variety of residues of amines and derivatives.

TABLE 6

\begin{tabular}{|c|c|c|c|}
\hline Cases & $\begin{array}{l}\text { Age at } \\
\text { death }\end{array}$ & $\begin{array}{l}\text { Age } \\
\text { now }\end{array}$ & Tumours \\
\hline 2 coopers $\ldots \quad \ldots$ & $\begin{array}{l}64 \\
73\end{array}$ & - & $\begin{array}{l}\text { Carcinoma prostate } \\
\text { Carcinoma bladder }\end{array}$ \\
\hline 3 fitters $\quad \ldots \quad \ldots$ & $\begin{array}{l}71 \\
54 \\
-\end{array}$ & - & $\begin{array}{l}\text { Carcinoma bladder } \\
\text { Carcinoma bladder } \\
\text { Papilloma bladder } \\
\text {-recurrent }\end{array}$ \\
\hline $\begin{array}{l}1 \text { cleaner and laun- } \\
\text { dryman for } 15 \\
\text { years }\end{array}$ & 60 & - & Carcinoma bladder \\
\hline $\begin{array}{l}1 \text { man working ad- } \\
\text { jacent to } \beta \text { - } \\
\text { naphthylamine } \\
\text { plant }\end{array}$ & 一 & 50 & Papilloma bladder \\
\hline
\end{tabular}

Particular attention must be drawn to the laundryman and cleaner, whose only contact with the suspected amines must have come about by badly contaminated clothing. To launder such clothing in hot detergent fluids (some likely to be alkaline) is to come into contact with liberated bases, some of which are volatile in steam : opportunity for absorption of various compounds per cutem is great : a recent determination of the amount of amines in process men's clothes (benzol extraction and fractionation) showed that several grammes of naphthylamines were impregnated in the fabric. As the man in question died as long ago as 1938 it may be considered as certain that the clothes he handled were more heavily contaminated than they would be in the improved conditions since.

The last case in Table 6 is that of a man who developed a bladder papilloma at age 48 after twenty-nine years in the industry. He was stated not to have had direct contact with any of the suspected amines but to have worked at various times on processes adjacent to the $\beta$-naphthylamine process (e.g. $\beta$-naphthol).

This table of cases (six bladder tumours) is in itself far from insignificant, in the twelve years in which it grew up, as an index of the high incidence of bladder neoplasms in this industry.

Prognosis.-We have already stated that routine cystoscopy is not practised in the factories being considered; reliance is placed on routine urine examination as a first sorting test, routine cystoscopy being carried out in hospital after the first diagnosis of a tumour by cystoscope and after operation.

It is recognized that in some cases the earliest appearance of a tumour may be missed and thus prognosis may be adversely affected. Whilst cystoscopy is not refused by a man who has once undergone operation as he is then apprehensive about possible recurrences, the position is quite different for a man who is symptomless and is dubious about the significance of even visible blood in his urine. To propose cystoscopic examination among workers in Britain at present would mean either mass evacuation of parts of the industry or a demand from all exposed men for a transfer to other work.

It must be emphasized again that the hazard of bladder carcinogens can only be properly and completely controlled by routine cystoscopy, as long as exposure to them continues.

In Table 7 the times of survival from first operation are given in seventy-two cases* in relation to the nature of the initial tumour.

The column heading " papilloma $\longrightarrow$ malignant " means that the initial diagnosis was papilloma and it was later found that malignant changes had appeared either at the original site or elsewhere. The term "first operation" has reference to any procedure designed to destroy or remove a growth (diathermy per urethram or open, partial cystectomy, total cystectomy). Inoperable cases were subjected to such operations as implantation of radon seed and deep $x$-ray therapy.

To summarize survival data completely requires that all the patients should be dead. In the summary given in Table 7 the incompleteness is due to the varying periods during which the surviving cases have been followed to date. This is due mainly to the varying times since the first operation was performed (some as recently as 1947 ; others as long ago as over ten years), and in some cases to the disappearance of the patient.

Table 7 summarizes what we know of the seventytwo cases up till 1948. Thus, for the twenty-eight cases diagnosed as papilloma and operated, we see that four were dead and fourteen were still alive five years after the first operation. The remaining ten cases cannot be included in the five-year group since none has been observed for this time as yet. But for the three-year period after first operation we know that three were dead at that time and eighteen were still alive.

It will be noticed that for the papilloma cases only $7 / 28$ were dead even after thirteen years ; for the frankly malignant cases $25 / 28$ were dead after thirteen years; for the cases later developing

\footnotetext{
*All those cases for which operation details were available.
} 
malignancy $6 / 10$ were dead after thirteen years; and for the inoperable cases $6 / 6$ were dead in something over two years. It is manifest that the survival of the malignant cases is poor. Combining the malignant and papilloma $\longrightarrow$ malignant cases it is seen that 50 per cent. (19/38) were dead in less than one year from the first operation, and almost 70 per cent. (26/38) were dead in five years.

Regarding the whole series of seventy-two operated cases we see that half were dead in something over five years, and almost two-thirds (44/72) were dead in thirteen years.

Since forty-four cases had died after thirteen years it is clear that twenty-eight cases still survive. Of these sixteen have survived at least five years, seven at least ten years, and three have survived over thirteen years. Of these surviving cases, twenty-one were initially simple papillomata.

It is relevant to note that the very early deaths recorded above were in some cases due to postoperative catastrophes, such as pulmonary embolism, paralytic ileus, or heart failure.

To determine a quantitative estimate of prognosis in terms of the nature of the tumours is extremely difficult, perhaps impossible, having regard to the following considerations :

(a) The disease is diagnosed and comes to treatment at very variable stages of development towards malignancy. (Routine cystoscopy would probably overcome this.)

(b) The tendency to recurrence is very marked in some cases, less so in others. (c) Surgical treatment may be undertaken by surgeons of varying competence and skill. (Incomplete diathermy may accelerate tendency to malignancy.)

(d) The location of the tumour may determine a-fatal outcome even when the latter is of relatively low malignancy.

The high proportion (twenty-eight out of seventytwo) of operated cases who died in about one year or less from the time of first operation is an indication rather of the advanced stage at which the tumour is first met with than of the ineffectiveness of surgical methods. In some few cases death was due to such calamities as pulmonary embolism or paralytic ileus.

We are loath to lay any stress on mean survival times, the range being from $<1$ to $>13$ years.

Given a reasonably early diagnosis, a location not involving the orifices, satisfactory renal function, and prompt surgical intervention at the nonmalignant or pre-malignant stage, the prognosis of the first operation may be good enough for the patient to look forward to years of valuable working life. This depends, however, on periodic cystoscopic examination, the importance of which lies in avoiding the establishment of a tumour of malignant character.

Prognosis in an occupational disease cannot or should not be detached from the essential industrial criterion-that is, return to productive work. Treatment which prolongs life during its productive phase without, at the same time, making productive effort possible, cannot be regarded as having

TABLE 7

SUMMARY OF DATA AVAILABLE ON SURंVIVAL TIMES FROM FIRST OPERATION ON BLADDER TUMOUR

\begin{tabular}{|c|c|c|c|c|c|c|c|c|c|c|}
\hline \multirow[b]{2}{*}{$\begin{array}{l}\text { Year(s) } \\
\text { after } \\
\text { operation }\end{array}$} & \multicolumn{8}{|c|}{ Nature of initial tumour } & \multirow{2}{*}{\multicolumn{2}{|c|}{$\begin{array}{c}\text { Total } \\
\text { (72 cases) }\end{array}$}} \\
\hline & \multicolumn{2}{|c|}{$\begin{array}{l}\text { Papilloma } \\
\text { (28 cases) }\end{array}$} & \multicolumn{2}{|c|}{$\begin{array}{l}\text { Malignant } \\
\text { (28 cases) }\end{array}$} & \multicolumn{2}{|c|}{$\begin{array}{c}\text { Papilloma } \rightarrow \\
\text { malignant } \\
\text { (10 cases) }\end{array}$} & \multicolumn{2}{|c|}{$\begin{array}{l}\text { Inoperable } \\
\text { (6 cases) }\end{array}$} & & \\
\hline $\begin{array}{c}0-1 \\
1- \\
2- \\
3- \\
4- \\
5- \\
6- \\
7- \\
8- \\
9- \\
10- \\
11- \\
12- \\
13-\end{array}$ & $\begin{array}{l}1 \\
1 \\
1 \\
3 \\
4 \\
4 \\
4 \\
5 \\
5 \\
6 \\
6 \\
7 \\
7 \\
7\end{array}$ & $\begin{array}{r}27 \\
27 \\
23 \\
18 \\
16 \\
14 \\
11 \\
9 \\
8 \\
6 \\
4 \\
3 \\
3 \\
1\end{array}$ & $\begin{array}{l}16 \\
19 \\
21 \\
22 \\
22 \\
23 \\
23 \\
23 \\
24 \\
24 \\
24 \\
24 \\
24 \\
25\end{array}$ & $\begin{array}{r}12 \\
9 \\
7 \\
5 \\
5 \\
4 \\
4 \\
4 \\
2 \\
2 \\
2 \\
1 \\
1 \\
0\end{array}$ & $\begin{array}{l}3 \\
3 \\
3 \\
3 \\
3 \\
3 \\
4 \\
4 \\
4 \\
5 \\
5 \\
5 \\
5 \\
6\end{array}$ & $\begin{array}{l}7 \\
7 \\
7 \\
6 \\
6 \\
6 \\
5 \\
5 \\
5 \\
4 \\
4 \\
3 \\
3 \\
2\end{array}$ & $\begin{array}{l}3 \\
5 \\
6 \\
6 \\
6 \\
6 \\
6 \\
6 \\
6 \\
6 \\
6 \\
6 \\
6 \\
6\end{array}$ & $\begin{array}{l}3 \\
1 \\
0 \\
0 \\
0 \\
0 \\
0 \\
0 \\
0 \\
0 \\
0 \\
0 \\
0 \\
0\end{array}$ & $\begin{array}{l}23 \\
28 \\
31 \\
34 \\
35 \\
36 \\
37 \\
38 \\
39 \\
41 \\
41 \\
42 \\
42 \\
44\end{array}$ & $\begin{array}{r}49 \\
44 \\
35 \\
29 \\
27 \\
24 \\
20 \\
18 \\
15 \\
12 \\
10 \\
7 \\
7 \\
3\end{array}$ \\
\hline
\end{tabular}

$* D=$ deaths. $\quad S=$ surviving cases. (Repetition of figures in the columns signifies unchanged numbers of dead or surviving cases and not additional numbers of dead or 
succeeded although in its human aspect it may be most gratifying. Regarded from this point of view, of the seventy-two cases given above some thirty were never able to return to work of any kind.

Recurrences.-A characteristic feature of this disease is the tendency to recurrences of tumours. The phenomenon is one of sprouting rather than of recurrence, although occasionally new tumours appear at old sites. The destruction by fulguration of a localized tumour or perhaps an area of small tumours may be followed after an interval by a newly-sprouted tumour whether exposure to the carcinogenic compounds has continued or ceased.

In the following tabulation are given some examples of the periods at which recurrences were found.

$\begin{array}{ccc}\text { Patient } & \begin{array}{c}\text { No. of } \\ \text { recurrences }\end{array} & \begin{array}{c}\text { Successive } \\ \text { periods (months) }\end{array} \\ \mathrm{Ai} & 1 & 8 \\ \mathrm{Ar} & 2 & 8,36 \\ \mathrm{~B} 1 & 4 & 15,20,15,88 \\ \text { Geo } & 2 & 7,21 \\ \mathrm{Ke} & 2 & 2,4 \\ \mathrm{La} & 1 & 24 \\ \text { McN } & 1 & 48 \\ \text { Me } & 1 & 20 \\ \text { Mitch } & 4 & 16,28,11,9 \\ \text { Rob } & 3 & 7,3,3 \\ \text { Uns } & 1 & 17 \\ \text { Walk } & 1 & 1 \\ \text { Whi } & 1 & 8 \\ \text { Wo } & 3 & 16,5,8 \\ \text { Br } & 1 & <12 \\ \text { Car } & 1 & 6\end{array}$

This tendency is of very great importance especially in the case of men who, recovered from a first operation, decide to leave the industry and disappear from continued control.

Inasmuch as this tendency remains throughout the life of the affected person, it is apparent that the responsibility for compensation is a liability that can cease only on his death. To restrict compensation to a loss of faculty developed during employment in the hazardous processes or whilst liable to be affected by the dangerous compounds is to ignore the essential nature of the disease. Difficult as it would be in practice, the responsibility should be laid upon the men while continuing in the industry and after leaving it to present themselves regularly for appropriate investigation. To make such a proposal work it will be necessary to have every man engaged in these processes on a special list which would make it possible to identify and locate him and to trace his works history. It would be quite unfair to leave the worker the onus of obtaining advice for, with a furtive disease such as this, he is in many cases unlikely to suffer loss of faculty before it is too late to save him. If done in this way and with the assistance of persons expert in this disease, frivolous claims are not likely to arise. Corresponding obligations would fall on the employers, such as approved methods of works' medical control, organization of accurate record of nature and duration of certain categories of operation and process, introduction of approved methods of manufacture, approved methods of ablution and of amenities, approved types of works apparel and safety measures, regular determination of atmospheric conditions, and routine inspection of plant.

Parallel with all this, research should be carried out to circumvent the present need to manufacture the free carcinogenic bases.

Metastases.-It is not uncommon to find it stated, less nowadays than formerly, that occupational tumours of the bladder do not give rise to metastatic deposits. Whilst it is true that some cases of very advanced carcinoma of the bladder do not appear to be associated with metastases even when the pelvis is a mass of matted malignancy, it is certainly true that secondary deposits may be found in a certain number of cases, of a highly malignant kind. Table 8 presents some data on this point.

Other observers of this disease have described metastases in the vertebræ, brain, lungs, and liver, as well as in the lymph glands in adjacent or distant parts of the body.

Considering the (not inconsiderable) size of the present series, it is clear that metastases are relatively uncommon in this disease.

Tumours of the Excretory Passages other than the Bladder.-Tumours of the pelvis, ureter, or prostatic urethra are very rare compared with those of the bladder. This is true both for occupational and non-occupational tumours. Considering that these parts (calyces, pelvis, ureter, bladder, prostatic urethra) constitute bọth functionally and histologically a unit system, this fact is not readily comprehensible, but, we hold, more reasonably explained on the hypothesis of a urinary carcinogen. The blood-borne carcinogen theory seems inadequate to explain this fact since the blood supply to all those parts is very similar. The layers of epithelial cells in the pelvis and ureter are fewer in number than in the bladder so that it might be thought likely that the absolute amount of a systemic carcinogen which, issuing from the closely applied sub-epithelial capillaries, would come into contact with a given number of epithelial cells would be higher in these parts than in the bladder (assuming no great difference in the density of the capillary network). In the trigone the density of vascular supply is greater than elsewhere in the excretory passages and so might permit a greater 
exposure of its epithelium to a systemic carcinogen. The bladder (even excluding the trigone) is incomparably more frequently the site of tumours than the ureter, pelvis, or prostatic urethra, a fact which demands some hypothesis more potent than the blood-borne carcinogen theory to explain it.

Whatever theory is adopted the rational explanation of tumours arising many years after exposure has ceased can only lie in one or more of the following :

(a) Modification of parts of the epithelium which in the course of years become neoplastic (some form of undetectable metaplasia during exposure).

(b) Modification of parts of the epithelium which renders the cells more susceptible to the attack of a carcinogen when the latter appears (this modification is a potentiation).

(c) Retention for years of minute amounts of the urogenous carcinogen in the bladder tissue, the ultimate tumour effect being delayed but inevitable (theory of direct amine carcinogen).

The fact that the process of tumour formation may begin as a sub-epithelial vascular reaction lends no support to either the systemic or urogenous theory, for sub-epithelial reactions of this kind can occur after amines are instilled directly into the bladder of animals or injected parenterally or given by mouth.

Support for the urinary theory rests largely on the anatomy and physiology of the excretory passages. The whole apparatus from the calyces and pelvis to ureter, bladder, and prostatic urethra is lined with transitional epithelium and is adapted to a simple process of collection and transmission of fluid, the bladder adding a more complicated process for expulsion. The funnel shape of the minor calyces and pelvis emphasizes the adaptation to the function of collection and transmission.
The estimated volume of the calyces and pelvis of one normal human kidney is about $8 \mathrm{c.cm}$. The rate of secretion from the kidney is subject to very wide variations. To permit such wide variations it is essential that the excretory passage shall not only offer no static obstruction but should assist in the disposal of fluid entering them from the renal papillæ. This latter is brought about by the provision of smooth muscle (two longitudinal and one middle circular layers) along the entire chain of excretory passages. The active participation of the smooth muscle system is visible cystoscopically when the ureters squirt out the urine into the bladder.

This process is continuous and in the normal subject the contact with the calyces, pelvis, and ureter is of very short duration for any particular volume of urine.

If, as we believe, the bladder carcinogen (or potentiator) is carried in the urine, the intensity of its action will depend on the concentration, the time of action, and the intimacy of contact with the cells. When the active agent passes over the calyces, pelvis, and ureter, intimacy of contact is certainly not obtained as it is in the bladder both between acts of micturition and after micturition when small residues of urine remain engaged in the rugæ in the bladder generally; but in the trigone, which is firmly fixed and traversed by fine folds radiating from the internal urethral orifice, there is likely to be less intimate contact after micturition since the surface is smoother.

The very frequent location of the occupational tumours near the ureteric orifices calls for an explanation based upon some structural feature of this area. Inasmuch as the ureteric orifices form two of the apices of the trigone, the contribution made by the long contact with urine applies also to the

TABLE 8

\begin{tabular}{|c|c|c|c|}
\hline \multicolumn{2}{|c|}{ Patient } & Nature of primary tumour of bladder & Secondary growths \\
\hline Beau & .. & Inoperable cancer from dome to trigone & Liver riddled with large secondaries. \\
\hline Mid .. & $\cdots$ & $\begin{array}{l}\text { Semi-sessile tumours growing in lower end of } \\
\text { ureters into lumen of bladder }\end{array}$ & Lymph glands showed secondary growth. \\
\hline Mitch & $\cdots$ & $\begin{array}{l}\text { Papilloma on posterior wall } \\
\text { Carcinomatous mass on anterior wall }\end{array}$ & $\begin{array}{l}\text { Left kidney showed area of secondary carcinoma } \\
\text { and pyonephrosis. }\end{array}$ \\
\hline Murph & . & Inoperable sessile infiltrating cancer & $\begin{array}{l}\text { Enormous mass of malignant lymph glands in } \\
\text { lumbar region. Mediastinum contained large } \\
\text { mass of malignant glands-all transitional cell } \\
\text { carcinoma. Nodule of secondary carcinoma in } \\
\text { left kidney. } \\
\text { Hydro and pyo-nephrosis. }\end{array}$ \\
\hline Whi & .. & Squamous cell carcinoma invading muscle coat & Right inguinal gland-carcinomatous.' \\
\hline
\end{tabular}


ureteric region but an additional contribution is probably made by the presence of the plica ureterica which, with the adjacent rugæ can bring about a local relative stasis of urine.

The question of concentration is important. It can be shown that aromatic amines are excreted rapidly both by man and animals, that is, the concentration in the blood does not rise to high levels whereas the amine urinary concentration rises steeply and falls less steeply but rapidly. Thus, at a time when the calyces are receiving a urine of low or even indeterminable amine content, the bladder may still be in intimate contact with amine (and derivatives) excreted at earlier stages and may continue so for hours.

It is, we suggest, important not to assume that the conditions which the carcinogen (or potentiator) meets in the bladder are identical with those met with in the ureter, pelvis, and calyces. In the bladder the urine reaction may be different from that of " renal urine": it may contain bacteria, epithelial cells, yeast cells, mucus from the vesical glands, gaseous compounds derived from the lower gut. It is conceivable that such factors may have some bearing upon the selective attack on the bladder by the amines or active derivatives.

In the present series of cases primary tumours of the excretory passages other than the bladder were confined to one indubitable case. This was a man who entered the industry at twenty-three years of age, worked from age twenty-seven till the age of thirty-four in processes involving $\beta$-naphthylamine, and developed three bladder papillomata which were fulgurated per urethram. Some eight months later he was found to have a fresh papilloma near the left ureteric orifice, which was also fulgurated successfully. One year and eight months later recurrence of signs with negative cystoscopic examination led to the discovery of a new growth in the pelvis of the right kidney. The kidney and ureter were removed. Growing from the pelvis were two papillomata (fig. 5), one about the size of a table-tennis ball and the other about $\frac{1}{3}$ in. in diameter. In addition, at the lower end of the ureter a small papilloma was found. These tumours were typical papillomata with no signs histologically of malignancy; the pelvic tumour was infiltrated with lymphocytes.

This was therefore, a case of papillomatosis with recurrences. The tumour in the kidney must have grown after the bladder tumours in view of the considerable period of freedom from signs or symptoms. The nature of the tumours leaves no doubt that they were primary. The tumours in the ureter may have been an implantation.

The occurrence of only a single case of this kind in the present series is, in our view, strong evidence that the carcinogen, whatever it may be, is urine borne.

\section{Summary}

1. The incidence of bladder tumours in two chemical factories in Britain is presented.

2. The following numerical characters of the disease emerge from analysis of the series :

Mean period from first entry into the industry till first discovered tumour :

18.95 years (S.E. 0.8) 100 cases

Mean age at first recognition of tumour : 50.55 years (S.E. 1.1) 93 cases

Mean age at death from tumour : $54 \cdot 2$ years (S.E. 1.35) 60 cases

Mean age at death in relation to age at first entry into the industry :

47.7 years (S.E. 1.8) - 28 cases entering at less than 30 years of age

55.9 years (S.E. 1.7)-18 cases entering between 30 and 40 years of age.

67.1 years (S.E. 0.37)-13 cases entering between 41 and 52 years of age.

These data indicate that the earlier the industry is entered the earlier is death likely to occur if $a$ tumour is contracted.

2. Comparison with the Registrar General's reurns of deaths due to tumours of the urinary tract shows that the proportion of deaths at ages less than 45 years due to occupational tumours of the bladder far exceeds that for urinary tumours in the general population.

3. Although, of the primary aromatic amines only $\beta$-naphthylamine has been shown experimentally to produce bladder tumours in dogs, evidence is presented that cases arise among workers who have been engaged not only exclusively in $\beta$-naphthylamine but also among others engaged exclusively in aniline, benzidine, and $\alpha$-naphthylamine (containing small percentage of the $\beta$-isomer).

4. The present series of cases suggests that bladder tumours arising in workers who have been engaged in $\beta$-naphthylamine or in more than one of the amines mentioned are more likely to be malignant from the start than those arising in workers engaged in one only of these amines.

5. Figures are given showing the order of excretion of aromatic amine in the urine of workers engaged in the manufacture of $\alpha$-naphthylamine.

6. Figures are given showing the survival times after operation hitherto recorded among the present series. 


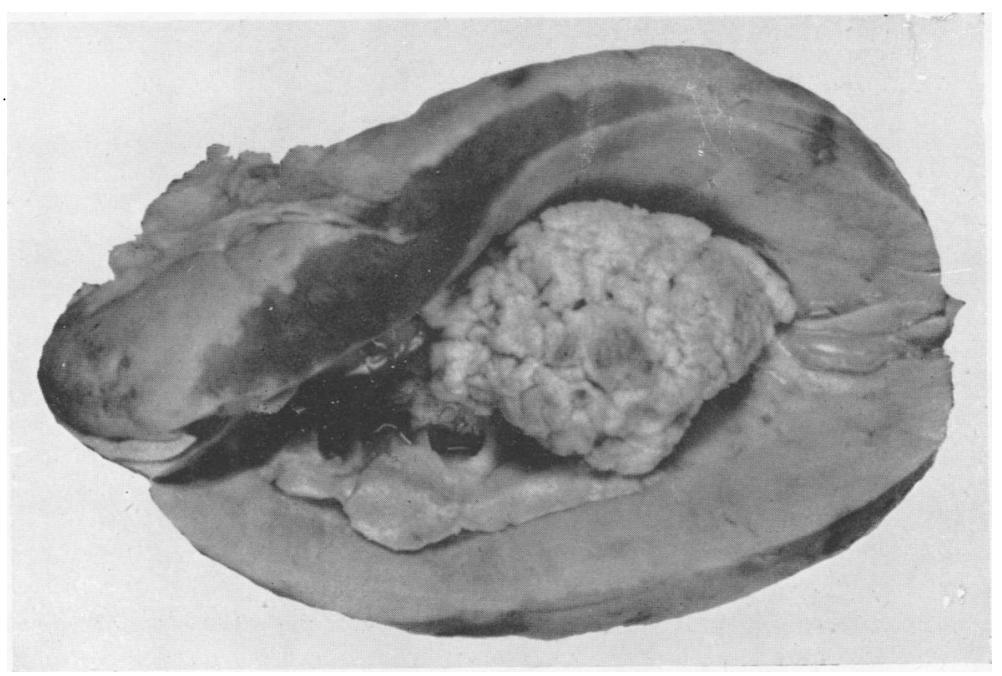

FIG. 5-Papillomata of renal pelvis in a chemical worker (see text).

7. Recurrences (freshly sprouted tumours in the main) are a feature of the disease and may appear from as little as a month or two after operation to as long as seven years after. Recurrences may appear long after leaving the industry.

8. Cases are recorded among workers who had been exposed in occupations ancillary to manufacture and use of the carcinogenic amines.

9. Metastases were found in only five cases of malignant disease of the bladder coming to autopsy. Metastases are thus relatively very uncommon.

10. Tumours of the excretory passages other than the bladder are very rare. One case of an undoubted primary tumour of the renal pelvis is described.

11. Brief indications are given of possible improvements in process operation which could contribute to elimination of the disease and which have proved valuable in practice.

12. It is held that the so-called amino carcinogens are only indirectly responsible for the tumour formation in that they sensitize or potentiate the tissue to the true carcinogen.

It is held that the amino potentiator (carcinogen as it is now called) is carried in the urine.

It is a pleasure to express my appreciation for their helpful efforts to Dr. C. Cresdee and to the managers and chemists in the factories concerned as well as to the urologists in the hospitals to whom the cases were submitted for cystoscopy and operation.

It is also a pleasure to express my grateful thanks to Miss Rachel MacHatton, B.Sc., for her great help in the preparation of this paper.

\section{REFERENCES :}

Billiard-Duchesne, J. L. (1947). J. Urol. méd. chir., 53, 401. - (1948). Arch. Mal. prof., 9, 109.

Bonser, G. M. (1943). J. Path. Bact. 55, 1.

Bonser, G. M. (1933). Ann. Rep. Chief Insp. Fact., H.M.S.O. London. Bridge, J. C. (1933). Ann. Rep. Chief Insp. Fact., H.M.S.O. London.

Desoille, H., Hochfeld, N., and Aboulker, P. (1948). Arch. Mal.
prof., 9, 149.
Engel, H. (1937). In W. C. Hueper "Occupational Tumours and Allied Diseases." Springfield, Illinois. , (1942). Ibid.

Gehrmann, G. H. (1936). J. Amer. med. Ass., 107, 1436.

Goldblatt, M.W. (1947). Brit. med. Bull., 4, 405.

Gross, E. (1940). Angewandte Chemie, 53, 368.

Hueper w C (1946) J. Amer med. Ass. $3,738$.

Koelsch, F. (1935). "Handbuch der Berufskrankheiten." Jena.

di Maio, G. (1937). "Tumori e Lesioni precancerose della vescica da amine o nitroderivati (dette da anilina)." Bologna; L. Cappelli.

Muller, A. (1933). Z. urol. Chir., 36, 202. 